\title{
The effect of entrepreneurial orientation variables on business performance in the SME industry context
}

Orientation variables on business performance

\author{
Ni Made Wahyuni
}

Management Study Program, Faculty of Economics, Warmadewa University, Bali, Indonesia, and

I Made Sara

Development Economics Study Program, Faculty of Economics, Warmadewa University, Bali, Indonesia

\begin{abstract}
Purpose - The purpose of this study is to provide new practical and theoretical insights into how small and medium-sized enterprises (SMEs) adjust and further develop business competencies, innovations and performance by using market orientation, learning orientation behaviors and entrepreneurial orientation.

Design/methodology/approach - The data was collected from manufacturing SMEs of textile products that had a number of employees between 5 and 99 people in the province of Bali, Indonesia, in 2016. Bali province was chosen as a research location because Bali was one of the tourism centers in Indonesia and even in the world was considered suitable for this research. It was because it had textile product industries that contributed in the fulfillment of the needs of tourism clothing, national economy, the fulfillment of fashion needs and foreign exchange contributors from non-oil exports (Industry and Trade Service of Bali).

Findings - Based on the results of descriptive and inferential analysis that has been conducted, it can be concluded that the answer to the problems and objectives that have been determined is market orientation, learning orientation and entrepreneurial orientation affect business performance through knowledge competence and innovation directly and its influence is significantly positive. But market orientation, learning orientation and entrepreneurial orientation do not directly have a significant positive effect on innovation through knowledge competence. Market orientation, learning orientation and entrepreneurship orientation indirectly have a significant positive effect on business performance through knowledge and innovation competencies.

Originality/value - The lack of studies in the existing literature underscores the potential contribution of this subsequent study. The novelty of the research is first to develop a concept of learning orientation that is linked to competence of knowledge, which this link has not been much expressed in the context of industry SMEs; second, to build the concept of innovation development of small and medium-sized industry of textile industry based on market orientation by strengthening the mediation role of competence of knowledge.
\end{abstract}

Keywords Performance, Innovation, Learning orientation, Market orientation, Competence of knowledge, Entrepreneurial orientation

Paper type Research paper

\section{Introduction}

In Indonesia, small and medium-sized enterprises (SMEs) play a big role when it is related to economic and domestic social issues such as high poverty rates, unemployment, inequality distribution, uneven processes and urbanization problems with all the negative outcomes. It can be interpreted that the existence and the development of SMEs are expected to give significant contribution to repair the problem.
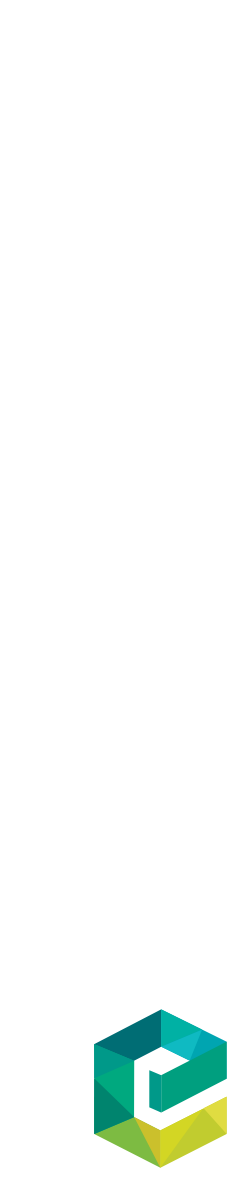
JWL 32,1

In Bali Province, SMEs are part of the business that sustains community life. This is in accordance with Law No. 3 year 2014 on Industry, which stated that industry was held for the purpose of:

- contribution of manufacturing sector to GDP;

- employment; and

- contribution of industrial commodities for goods and service export.

Industries in Bali when seen from the number of business units, was 8,706 business units (2010) rose to 12,084 business units (2014) with an average increase of 8.98 per cent per year. Textile industries and textile products become one of the backbone of manufacturing SMEs that are still prospective to be developed in Bali. The export opportunities of the textile industries and textile products are still quite large in terms of Indonesia's high textile exports, with 62 per cent per annum on average total exports, and Indonesian textile exports reach US $\$ 10.83 \mathrm{bn}$ (Industry and Trade Service of Bali Province, 2015). Indonesia's textile export potential targets are the USA, Australia, Middle East, Europe and Japan (Kompas, 2014).

SMEs of the textile industry have shown their achievement in terms of export value during the period 2012-2016, but the growth trend has decreased (Industry and Trade Service of Bali Province, 2017). Indications of an industry's development are reflected in improved business performance. Business performance is determined by internal capabilities and the role of external environment (Salleh et al., 2010). Internal factors and the role of external environment such as government role, consumer preference and globalization affect business performance. The era of globalization characterized by technological advances, uncertainty, changes in consumer preferences, and the age of increasingly short innovations require companies to protect themselves from competitors' pressures. Competition becomes appropriate and the core of success, when companies are able to adapt, change and build a culture of innovation (Wong, 2013).

It has universally been recognized that the key to corporate survival is innovation (Saunila et al., 2014; Batra et al., 2015). Innovation is described as the successful implementation of creative ideas within an organization (Otero-Neira et al., 2009). The concept of innovation from an organizational perspective is described as the ability to create something new or bring about renewal, change, and behavior by using existing abilities (Rhee and Lee, 2010). Organizational skills in transforming knowledge and ideas into new processes, systems, or products show an innovation (Huhtala et al., 2014).

Research has reached consensus that innovation has a positive effect on business performance from the perspective of market share growth, productivity, sales and profitability (Jimenez and Valle, 2011; Al-Ansari et al., 2013; Saunila, 2014; Hilman and Kaliappen, 2015). However, there are still other researchers who find the effect of innovation on business performance insignificant (Darroch, 2005; Hilmi et al., 2010). It is not easy for companies to improve business performance, without innovation. Given the importance of innovation in relation to the company's competitive position, then the question is how to improve organizational innovation. A number of researches have tried to identify the key determining factors of company capacity to innovate (Damanpour, 1991; Keskin, 2006). The internal factors that is able to strengthen the innovation, such as organizational culture and abilities (Clulow et al., 2007). The literature highlights the variables of market orientation and innovation (Huhtala et al., 2014; Newman et al., 2016), the relationship of learning orientation and innovation (Calantone et al., 2002; Mauludin et al., 2013; Mahmoud et al., 2016) and the relationship of competence of knowledge and innovation (Griese et al., 2012; Ozkaya et al., 2015) as an antecedent of innovation and its consequences to business performance. 
From the practitioners' point of view, the question arises as to what factors are the keys to the success rate of innovation and business performance in the context of industrial SMEs in Bali. From a theoretical point of view, the question arises as to how innovation and success of manufacturing SMEs can be explained by a model of market orientation, learning orientation and integrated knowledge competence.

Implementation of marketing concept philosophy shows market orientation. Resourcebased view (RBV) theory asserts that competitive advantage and business performance are determined by resources (Wernerfelt, 1984; Barney, 1991; Najafi-Tavani et al., 2016). One's market orientation can be seen from the level of customer orientation, its orientation to competitors and its inter-functional coordination (Narver and Slater, 1990; Huhtala et al., 2014). Managers who build market orientation contribute to organizational innovation skills (Zhang and Duan, 2010; Wang and Chung, 2013). Likewise with textile product managers in Bali, they need to improve market-oriented behavior by actively exploiting external opportunities through interaction with customers into internal resource capabilities to improve innovation capabilities. In this case, organizations with a high degree of market orientation tend to encourage knowledge competence. Market orientation as an organizational culture that seeks to understand customers improves learning mechanisms so that knowledge competence increases (Harmancigolu et al., 2010).

Experts have recognized the importance of learning orientation toward business performance (Calantone et al., 2002). Learning orientation creates new information and knowledge, and uses existing knowledge effectively from external sources and obtains information (Mauludin et al., 2013). Organizations with high learning orientation will exhibit responsive behaviors to environmental change, i.e. market and customer developments (Frank et al., 2012). Learning orientation as an activity of creating knowledge leads companies to learn faster than competitors in enhancing knowledge and skills, leading to superior performance (Haryanto et al., 2017).

According to the theory of RBVs, organizational capabilities such as knowledge competence are a tool for gaining competitive advantage (Atuahene-Gima and Wei, 2010). Knowledge competence has become an organization's strategic asset. Ozkaya et al. (2015) examines the relationship of knowledge and innovation competence to large corporations in the United States and China, where the literature provides evidence that the higher the knowledge competence is, then the greater the level of innovation. Knowledge competence leads to the process of acquiring knowledge, by processing information that enables a company to minimize the risk of miscalculation of the needs of the buyer and the company in creating an innovation opportunity. Knowledge competence as a company's ability to identify information and acquire new knowledge from external sources tends to allow companies to adopt new ideas, processes and products (Chang et al., 2015).

It has been universally acknowledged that the key to the sustainability of the company is innovation. (Saunila et al., 2014; Batra et al., 2015). Innovation is illustrated as the success of creative ideas implementation in an organization (Otero-Neira et al., 2009). Innovation concept from the organizational perspective is illustrated as an ability to create something new or bring a novelty, modification and a behavior by using the existing ability (Rhee and Lee, 2010). Organizational skill to modify knowledge and idea to the process, system, or a new product shows an innovation (Huhtala et al., 2014). The research has been a consensus that innovation has a positive impact on business performance from the perspective of market share growth, productivity, sales and profitability (Jimenez and Valle, 2011; A1Ansari et al., 2013; Saunila, 2014; Hilman and Kaliappen, 2015). However, the relationship between innovation and business performance has never been consistent. There is still another study that finds that the effect of innovation on business performance is not 
JWL 32,1

significant (Darroch, 2005; Hilmi et al., 2010). However, it is not difficult for a company to improve business performance without having innovation. When realized the importance of innovation in its relationship with the company's competitive position, a large amount of literature highlights the potential of important variables leading to the innovation and business performance. A number of studies try to identify the main determinant factor of company capacity to innovate (Damanpour, 1991; Keskin, 2006). Internal factor is able to support innovation, such as organizational culture and ability (Clulow et al., 2007). The literature highlights market orientation variable (Huhtala et al., 2014; Newman et al., 2016), learning orientation (Calantone et al., 2002; Mauludin et al., 2013; Mahmoud et al., 2016) and knowledge competence (Griese et al., 2012; Ozkaya et al., 2015) as an antecedent of innovation and its consequence of business performance. Market orientation as an implementation of marketing concept has been an important concept for a company's success. In recent years, the study has introduced many market orientation ideas as an important trend. An empirical study has been carried out to test the relationship between market orientation and business performance. RBV theory emphasizes that competitive advantage and business performance is determined by resources (Wernerfelt, 1984; Barney, 1991; Najafi-Tavani et al., 2016). Someone's market orientation as an organizational culture can be seen from the level of customer orientation, its orientation to the competitor, and inter-functional coordination (narver and Slater, 1990; Huhtala et al., 2014). A manager who builds market orientation contributes to the organizational innovation skill (Zhang and Duan, 2010; Wang and Chung, 2013) and business performance (Saunila et al., 2014).

In addition, Calantone et al. (2002) have admitted the importance of learning orientation to the innovation and business performance. A study in the marketing field emphasizes that learning orientation creates information and new knowledge and uses the existing knowledge effectively from the external source and get information (Westerlund and Rajala, 2010). An organization with a high level of learning orientation will show responsive behavior to the environmental change, which is market and customer orientation (Mauludin et al., 2013). Learning orientation as an activity to gain knowledge causes a company to learn more quickly than the competitor in terms of improving knowledge and skill that leads into the knowledge competition (Griese et al., 2012; Foong and Khoo, 2015), innovation (Rhee and Lee, 2010) and an advantage business performance (Frank et al., 2012; Haryanto et al., 2017).

RBV theory decides resource as an organizational capability like a knowledge competition is a way to get a competitive advantage (Kandemir, 2005; Atuahene-Gima and Wei, 2010). Knowledge competence has been an organizational strategic asset (Li and Calantone, 1998). Organizational tendency to scan market to understand trend and circumstance in a business environment, to share through transformation among the relevant user, information interpretation to become knowledge and the utilization of knowledge as a base of action shows the level of knowledge competency influenced by market orientation (Kandemir, 2005).

What Kaya et al. (2005) found in accordance with the relationship between knowledge competition and company innovation in the USA and China proves that the higher the competency, the bigger the innovation level. Knowledge competence leads to the process of gaining knowledge by processing information that enables a company to minimize the risk of miscalculation of buyer and company needs in creating an innovation change. Knowledge competence as a company's ability to identify information and gain new knowledge from the external sources tend to enable the company to adopt ideas, processes, and new product (Chang et al., 2015). A study conducted in a market of a developed country that has a different still relatively small context of culture, social and economy. There is no published literature that has studied the impact of market orientation, learning orientation on the 
innovation and business performance by strengthening a knowledge competency role in the context of SMEs manufacturing in Indonesia.

The positive role of innovation on performance has been supported by many empirical studies (Calantone et al., 2002; Keskin, 2006). Innovation is a reflection of environmental uncertainty, the turbulence of the business environment that encourages the adoption and development of new ideas, processes, services, products into business performance determinants (Vicence et al., 2015). As a result, this research seeks to explore the common implications of the level of market orientation, learning orientation on knowledge competence, innovation, and business performance in the context of SMEs of the textile product industry. The lack of studies in the existing literature underscores the potential contribution of this subsequent study. Thus, the purpose of this study is to provide new practical and theoretical insights on how SMEs adjust and further develop business competencies, innovations and performance by using market orientation and learning orientation behaviors. Based on the description, this study explains the effect of learning orientation on knowledge competence, the influence of market orientation and learning orientation toward knowledge competence and innovation, the influence of knowledge competence on innovation; the influence of innovation on business performance, the role of knowledge competence in mediating the effect of market orientation on innovation, the role of knowledge competence in mediating the influence of learning orientation toward innovation, the role of innovation in mediating the influence of market orientation on business performance and the role of innovation in mediating the effect of learning orientation on business performance.

The novelty of the research is first, to develop a concept of entrepreneurial orientation that is linked to competence of knowledge and business performance, which this link has not been much expressed in the context of industry SMEs; second, to build the concept of innovation development of small and medium-sized industry of textile industry based on market orientation by strengthening the mediation role of competence of knowledge; third, to build the concept of innovation development of small and medium-sized business of textile industry based on learning orientation by strengthening the mediation role of competence of knowledge; fourth, to investigate in an integrated and holistic manner the concept of market orientation, learning orientation, entrepreneurial orientation and competence of knowledge to strengthen the innovation ability and business performance of SMEs of textile industry in Bali.

This research contribution is to connect theoretically and to conduct an empirical test of the relationship between five important constructions. Hence, the purpose of this study is first to facilitate the role of market orientation, learning orientation, and knowledge competence to the innovation and business performance; secondly, to observe the effect of knowledge competence mediation in the relationship of market orientation and learning orientation to the innovation and business performance. This research is expected to bring a new theoretical view on how manufacturing SMEs adopts, develops and uses market orientation and learning orientation behavior to increase innovation and business performance by strengthening mediation role of knowledge competence. For that matter, the novelty of this research is first, to develop the concept of learning orientation related to the knowledge competence, in which this link has not been widely expressed in the context of manufacturing SMEs; second, to build a concept of innovation development of SME of textile industry based on the market orientation by strengthening mediation role in the knowledge competence; third, to build an innovation development concept of a SME of textile industry based on the orientation of learning by strengthening mediation role in the knowledge competency; fourth, to investigate in an integrated way and holistically with the concept of market orientation, learning orientation and knowledge competence to strengthen innovation ability and business performance of manufacturing SMEs. 
JWL 32,1

This study also elaborates the benefits will gain and gives a new insight for the practitioner to integrate operational pattern under the principle of market orientation and learning orientation to strengthen innovation, and business performance of manufacturing SMEs by improving the role of knowledge competency mediator. Especially, an effort is conducted to widen the existing study in the market orientation and learning orientation. SMEs context from textile industry provides some interesting insight. This study outlines the benefits and provides insight for practitioners to integrate patterns of operation with the principles of market orientation and learning orientation to strengthen knowledge competence, innovation and business performance of SME manufactures. In particular, efforts are made to expand existing research on market orientation and learning orientation. Little research has been found that investigates how market orientation and learning orientation strategies are capable of developing knowledge competence, innovation, and business performance. The context of SMEs of the textile product industry provides some interesting insights.

The paper is structured as follows: In Section 2, we will review the literature on market orientation, learning orientation, knowledge competence, innovation and business performance and will generate a conceptual framework of research. Section 3 describes the methodology applied for conducting the research. Section 4 elaborates results and discussion for this study. Section 5 summarizes the application of our findings and concludes with further prospects for research and business.

\section{Literature review and development of conceptual framework}

\subsection{Business performance}

Business performance shows the result of an organization (Saunila et al., 2014). Measuring business performance enables companies to focus on areas that need to be improved by assessing how well the work is done in terms of cost, quality, quantity and time (Skrinjar et al., 2008). According to Hult et al. (2004), business performance shows the achievement of organizational goals. Business performance is measured by using subjective measurements based on staff and manager perceptions. Operationally, business performance is measured by indicators of sales volume, profitability, and market share (Najib and Kiminami, 2011). The level of innovation contributes to business performance and helps companies to survive in markets (Jimenez and Valle, 2011; McDermott and Prajogo, 2012; Huhtala et al., 2014).

\subsection{Innovation}

Nowadays, fierce competition, endless turbulence and an uncertain environment force organizations to embrace innovation as a corporate strategy. Innovation becomes a strategic tool for companies in the face of changes in internal and external environment. Innovation is defined as the implementation of an idea regarding new devices, products, systems, processes, programs or services (Damanpour, 1991; Saunila and Ukko, 2012). Innovation is also defined as the ability of a company to seek something new or better by identifying, obtaining and performing tasks related to products, services, processes, administrative and management systems, marketing methods and organizational structures (Calantone et al., 2002; Brem and Voigt, 2009). The organizational trend to innovate can be seen from company indications to engage in new ideas, novelty, creative processes and experiments that will create new products/services (Lin et al., 2008).

The ability of managers to build market orientation contributes to the level of innovation. The culture and behavior of market orientation monitor how customers and competitors move in business. Market information obtained from customers and competitors helps companies to monitor markets and facilitate innovation (Lin et al., 2008). The market orientation through its relationship with customers creates product innovation (Roach et al., 
2014; Chang et al., 2015). Illeris (2004), in the workplace learning model, was echoed by other studies to show the difference in employees' perception regarding the learning practices effectiveness with a learning process (Fuller and Unwin, 2005), ever-changing work environment (Paloniemi, 2006), workplace that is considered as a learning environment or not (Coetzer, 2007) and employees' personal characteristics (Beitler and Mitlacher, 2007).

Orientation variables on business performance

\subsection{Market orientation}

Marketing literature has considered market orientation to be a key part of organizational culture (Carbonell and Escudero, 2010; Chung, 2012). Market orientation emphasizes the organizational culture that generates the behavior needed to create superior value for customers. Empirical research has found activities in which companies are engaged in new product development activities, linked to their market orientation level. Three behavioral components such as customer orientation, competitor orientation, and inter-functional coordination are key to organizational success (Narver and Slater, 1990; Wang and Chung, 2013). The willingness and effort of the company to collect market information (e.g. information on prices, desired products, customers, competitors, suppliers, government regulations and environmental changes) and disseminates information throughout the organization and responds to market intelligence shows examples of behaviors that reinforce a companyoriented identity market (Newman et al., 2016). Thus, we propose the following hypothesis:

H1. The more the market orientation increases, the stronger the innovation is.

\subsection{Learning orientation}

Sinkula et al. (1997) develop the original concept of learning orientation as a basic attitude toward learning that enables the organization to learn. Meanwhile, organizational learning is a dynamic process of knowledge accumulation (Frank et al., 2012). Learning orientation as an attitude or value system will influence the organizational tendency to create and use knowledge (Sheng and Chien, 2015). The level of organizational learning orientation is shown by the effort to develop new knowledge or insights that have the potential to influence behavior through values and beliefs (Huber, 1991). Wolff et al. (2015) introduces a conceptual framework of learning orientation as organizational values such as principles, morals, ethics and standards affecting organizational behavior that ultimately generate results. Organizational values consist of sets of values of learning commitment, shared vision and open-mindedness (Baker and Sinkula, 2005; Calantone et al., 2002). Thus, learning orientation requires the elements of open-mindedness and commitment to learning as a driver of organizational learning. Learning takes place when organizational members as learning agents respond to changes in the external environment and the internal environment by detecting and correcting errors in the use of organizational theory that allow the insights of decision makers to exploit opportunities (Wolff et al., 2015).

Learning orientation is a basic attitude toward learning that results in organizational learning processes (Sinkula et al., 1997). According to Wolff et al. (2015), learning orientation at least requires elements of commitment to learn and open-mindedness as a precursor for organizational to learn and successful adaptation. The organizational ability to learn is seen as a source of sustainable competitive advantage (Levinthal and March, 1993). The behavior to use the external opportunities and company's internal sources in supporting the organizational learning orientation will create innovation ability (Calantone et al., 2002; Chen et al., 2009; Raju et al., 2011; Calisir et al., 2013; Chang et al., 2015). Based on this evidence, we suggest:

H2. The more the learning orientation increases, the stronger the innovation is. 
JWL

32,1

\subsection{Entrepreneurial orientation}

Entrepreneurial orientation contributes to performance and is defined as a compound measure (compound, a combination of several components) that covers the dimensions of growth and also includes financial performance (Wiklund: 1999) so that courage to take risks, innovative and proactive attitudes will make companies- small companies can beat their competitors. In this case, the aggregate measurement of the concept of entrepreneurial orientation is based on the assumption that all three sub dimensions (innovation, proactivity and risk taking) make the same contribution to the overall level of entrepreneurial orientation of the company in all situations (Vitale et al., 2002). Nevertheless, several studies on entrepreneurship state that each of these sub-dimensions is likely to make a unique contribution to the entrepreneurial conditions of a company (Lumkin and Dess, 1996).

\subsection{Knowledge competence}

Competence approach focuses on internal factors. The term competence was first introduced by Selznick (1957), referring to things done very well by organizations rather than competitors (Kandemir, 2005). Competence is a collection of complex skills and collective learning that is done through organizational learning (Day, 1994). Competence is based on a set of capacities that deal directly with the knowledge, skills and attitudes of the individuals involved in the process. Competence is important for achieving competitive advantage (Barney, 1991; Griese et al., 2012). A RBV explains that knowledge competence is an intangible resource that significantly affects business strategy and performance (Li and Calantone, 1998).

Knowledge competence acts as the internal ability of the organization to achieve superior performance; thus, the company must be able to identify, seek, develop, use and maintain competence. Knowledge competence arises from market information gathering activities, information sharing and develop shared understanding of markets, followed by application of market knowledge to the formulation of marketing and implementation strategies (Kandemir, 2005; Foong and Khoo, 2015).

The successful goals include the successful knowledge-building efforts due to a match between internal strategic behavior and external environmental conditions (Chang et al., 2015). The positive attitude of the importance of learning orientation to increase the insight and knowledge play a role in improving competence of knowledge (Griese et al., 2012; Wu and Lin, 2013). Consequently, we propose the following:

H3. The more the market orientation increases, the higher the knowledge competence is.

Successful targets include successful knowledge development efforts due to a match between internal strategic behavior and external environmental conditions (Chang et al., 2015). The positive attitude of the importance of learning orientation to increase insight and knowledge plays a role in improving knowledge competence (Griese et al., 2012; Wu and Lin, 2013).

An attitude towards learning and intention to result and use knowledge indicates a learning orientation. An improving learning orientation is realized by a commitment to learning, share a vision and having an open mind and to seek for, spread and use information to improve competency (Hoe, 2008). A success target is categorized as a successful knowledge development effort because of suitability between internal strategic behavior and external environmental condition (Chang et al., 2015). The positive attitude of the importance of learning orientation to improve insight and knowledge plays an important role in improving knowledge competence (Griese et al., 2012; Wu and Lin, 2013). 
Organizational commitment to independently learn as an effort to have new knowledge shifts the created knowledge by inventing a knowledge competence (Foong and Khoo, 2015).

Therefore, we offer the following hypotheses:

H4. The more the learning orientation increases, the higher the knowledge competence is.

Knowledge competency relates to innovation. A study conducted by Maheswari et al. (2017) in India determines that the owner and manager of SME as a source of knowledge by conducting systematical activity including acquisitions, creation, saving, and sharing knowledge lead to innovation. An effort to collect information and conduct transformation information to market knowledge improves innovation (Li and Cavusgil, 1999; Harmancigolu et al., 2010). Competency enables a company to have a chance to make innovation and get a new product advantage (Bhatnagar and Gopalaswamy, 2017). An ability to change information to knowledge gives support for innovative behavior (Chang et al., 2015). Generally, knowledge competence has a positive effect on the idea success, a new product in every period, a new process and service (De Luca and Atuahene-Gima, 2007; Johnson and Atchison, 2009). For that matter:

Therefore, we offer the following hypotheses:

H5. The higher the knowledge competence, the higher the level of enterprise innovation is.

RBV theory sees innovation as a resource that facilitates a company to achieve a competitive advantage. A successful innovation is more considered as contributing factor to the business performance in several industries (Ndubisi and Iftihkar, 2012). Innovation helps a company to stay in the market (Jimenez and Valle, 2011). When a company has an ability to try a new idea or develop a product/service so that it will be able to offer an innovative product (Rosenbusch et al., 2010). The innovative product creates a new demand, and for that matter the sales volume, market share and the profits increase (Saunila and Ukko, 2012). Referring to the theoretical review supported by research result so the proposed hypotheses are as below:

Therefore, we offer the following hypotheses:

H6. The stronger the level of innovation, the higher the business performance is.

Recent research (Ozkaya et al., 2015) found that market orientation effects the innovation through the mediation of competence of knowledge variables. The competence of marketrelated knowledge shows the ability of a company to transform information into new product design knowledge (Li and Calantone, 1998; Kandemir, 2005). By knowing what customers want and what competitors do is important, but turning market information into innovative knowledge requires one different thing, namely, the competence of knowledge (Bhatnagar and Gopalaswamy, 2017). Organizational competence of knowledge can be developed through positive attitude of learning orientation and intention (Wu and Lin, 2013; Foong and Khoo, 2015). Based on this evidence, we suggest:

H7. Market orientation influences innovation through knowledge competence mediation.

Attitudes determine behavior, as well as the importance of learning which has a positive effect on the intention of behaving in increasing the knowledge (Foong and Khoo, 2015). Organizations have a view that learning is important for the future of the organization by continually striving to create learning by gathering information, sharing information and
Orientation variables on business performance 
JWL

32,1

using information that fosters the knowledge competence process (Fang et al., 2015). The learning orientation that occurs through organizational observation and interaction with the environment allows the company to create competencies related to market knowledge. Acquisition activities, dissemination and environmental scanning to collect information and create knowledge make the company more adaptive that contribute to innovation (Suliyanto and Rahab, 2012). Based on the description, the following hypothesis is proposed:

H8. Learning orientation influences innovation through knowledge competence mediation.

The findings of the literature show that information acquisition has an effect on innovation. The market orientation has a relationship with innovation (Wei et al., 2012). Market-oriented behavior tends to strengthen efforts to gather relevant information. Focus on transforming information into knowledge, that is, information gathered about customers and competitors creates knowledge competencies. Utilization of information and knowledge as a reflection of knowledge competence opens innovation opportunities (Gotteland and Boulé, 2006). Based on the description, the following hypothesis is proposed:

H9. Market orientation influences business performance through innovation.

Attitudes toward learning and the intention of generating and using knowledge become an indication of a learning orientation. Organizational commitment to self-learning as an effort to gain new knowledge replaces the knowledge that has been created by creating knowledge competence (Foong and Khoo, 2015). Increased learning orientation is realized with a commitment to learning, sharing of vision and having an open mind, seeking information, disseminating and using information to improve competence (Hoe, 2008). The ability to transform information into knowledge provides support for innovative behavior (Chang et al., 2015). Releasing ideas, new products in each period, new processes and services lead to improved business performance (Ndubisi and Iftihkar, 2012). Based on theoretical studies supported the results of previous research, the following hypothesis is proposed:

H10. Learning orientation influences business performance through innovation.

\subsection{Conceptual framework}

Based on the description in the framework of thinking, then, it can be arranged a research concept framework as seen in Figure 1.

\section{Methodology}

\subsection{Sample}

The data was collected from manufacturing SMEs of textile products that had a number of employees between 5 and 99 people in the province of Bali, Indonesia, in 2016. Bali province was chosen as a research location because Bali was one of the tourism centers in Indonesia and even in the world, was considered suitable for this research. It was because it had textile product industries that contributed in the fulfillment of the needs of tourism clothing, national economy, the fulfillment of fashion needs, and foreign exchange contributors from non-oil exports (Industry and Trade Service of Bali Province, 2017).

This research was conducted in Indonesia, given Indonesia is a developed country with economic power in Asia, has a diverse community both economically and socially, has a potential to become world economic power. In Indonesia, manufacturing SMEs plays an 


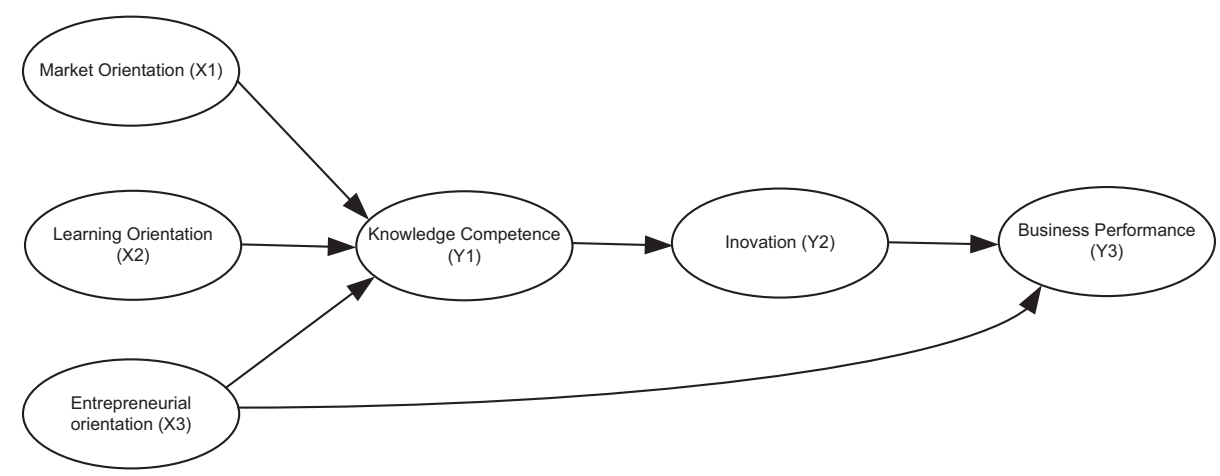

Orientation variables on business performance

important role if connected to the economic and social problem, such as high poverty level, jobless, a gap of distribution, uneven development and urbanization problem. The existence of manufacturing SMEs development is expected to give a significant contribution to the effort of solving that problem. Indonesia manufacturing SMEs is recently developing and innovative. However, this research is still limited to how manufacturing SMEs in Indonesia and what factors that give positive and significant contribution for innovation and business performance improvement. From the practitioner perspective, it raises a question about key factors of the success of innovation level and business performance in the context of manufacturing SMEs in Indonesia. From the theoretical point of view, it raises a question on how innovation and the success of the business performance of manufacturing SMEs can be explained by market orientation model, learning orientation and an integrated knowledge competence. As a result, this research tries to explore general implications from the level of market orientation, learning orientation and learning competence in innovation and business performance in the context of manufacturing SMEs. The lack of study in the existing literature underlines the potential contribution from the coming up study.

The population of this research was all of SMEs of textile industry in Bali which amounted to 125 textile industries. The number of samples taken referred to the Slovin formula (Fernandes and Solimun, 2017), which obtained the sample size of 94 respondents. The technique of determining the sample was stratified proportional random sampling method. Furthermore, the researchers used simple random sampling method in selecting the respondents. During the analysis, 24 of the 94 questionnaires had to be canceled for various reasons such as the company not meeting the definition of manufacturing SMEs and the response to incomplete questionnaires. For some reasons, 70 managers were available to be interviewed and to answer the questionnaire. Inferential statistical analysis techniques with path analysis approach were used to test the hypothesis. Data processing was done by path analysis approach by using GSCA with second-order confirmation factor analysis (Solimun and Fernandes, 2017; Indarti et al., 2017).

\subsection{Questionnaire design}

Quantitative research method based on positivism was used in this study for primary data collection. Quantitative approach was useful for data verification and confirmation. The primary data collected by the survey was data collected directly from respondents from direct interviews and respondents' perceptions of market orientation, learning orientation, knowledge competence and innovation and business performance. Structured question in questionnaire design used in this research was formulated based on literature review. The 
JWL 32,1

identified research variables were measured subjectively with a five-point Likert scale. This study considered the question of designing the questionnaire with care such as appearance, sequence and words. Details of the measurement items data were shown.

Validity and Reliability Test. The validity test shows how concrete a test is in measuring what is supposed to be measured. It is related to the accuracy of the measurement tools in functioning to reach a target and objective of a measurement. The research validity instrument was conducted using a method of correlation among statement point scores with a total score (indicator) within the level of significance 5 per cent or alpha of 0.05 . The statement points considered valid if it has a coefficient of positive correlation and is beyond 0.30 or the correlation coefficiency value $(\mathrm{r})>0.30$.

The reliability test is a test to show how far a measurement tool can be trusted or relied on. A scale or data measurement instrument, and the data generated can be considered reliable or trustworthy if the instrument consistently shows the same result every time a measurement is conducted. The reliability test was using a statistical test by measuring the Cronbach alpha. A research instrument is considered reliable if it has a Cronbach alpha beyond or equal to 0.60 (Latan and Ghozali, 2012, p. 50).

\subsection{Measures}

3.3.1 Market orientation. Market orientation (X1) was an organizational culture that created the behaviors necessary to generate superior value for customers. The measures of market orientation developed by Zhang and Duan (2010), Newman et al. (2016) which were adopted in this study consisted of three components of customer orientation (four items), competitor orientation (three items), and inter-functional coordination of management (three items).

3.3.2 Learning orientation. Learning orientation $(X 2)$ was the manager's orientation to learning that led to efforts to improve market knowledge and understanding to improve competitiveness. The measures of learning orientation developed by Calantone et al. (2002), Frank et al. (2012) and Wolff et al. (2015) which were adopted in this study consisted of a youth commitment (three items), shared vision (three items), and open-mindedness (three items).

3.3.3 Entrepreneurial orientation. Entrepreneurial orientation (X3) is the entrepreneur's behavior in finding new markets, serving customers, beating competitors in taking advantage of business opportunities and daring to do risky ventures. The measurement of entrepreneurial orientation in this study is consistent with Lumpkin and Dess (1996) measures; Vitale et al. (2002), and Keh et al. (2007), can be measured through three indicators namely innovative, proactive and risk.

3.3.4 Knowledge competence. Knowledge competence (Y1) was an organizational behavior that led to efforts to generate and integrate market information into market knowledge. To assess knowledge competence, this study adopted a knowledge competence item developed by Li and Calantone (1998) and Ozkaya et al. (2015) with three items, namely, the ability of the customer knowledge process, the ability of the customer knowledge process, good market knowledge.

3.3.5 Innovation. Innovation (Y2) was the ability of management to adopt, accept, and apply new ideas, products, mechanisms, processes or behaviors to gain competitive advantage. The measures of innovation was adopted from Nasution et al. (2011) and Roach et al. (2014), which consisted of product innovation (four items) and process innovation (four items).

3.3.6 Business performance. Business performance (Y3) was the result of management operations and strategies carried out over a given period. Because this research used multicompany, to control the difference in performance, business performance was measured by 
adopting the measures proposed by Al-Ansari et al. (2013) and Huhtala et al. (2014), subjective performance based on market effectiveness which consisted of three items, including market share growth, sales volume and profitability.

Data analysis technique: the descriptive statistical analysis was used to describe the respondents' characteristics and perception regarding the indicators of each research variable. This analysis used the average calculation and frequency to depict the profiles of the respondents and descriptions of the research variables. The descriptive statistical analysis was also used to describe the respondents' responses toward the questions. The respondents' responses can depict their perception regarding the indicators, which reflect the research variables.

The model in this research is the causality model (cause-effect relations), wherein the causal relationship formulated in this research used a model that is not simple. The form of causal relationship requires an analysis instrument that can explain the relationship, which is the inferential statistical analysis. The technique of inferential statistical analysis using the path analysis approach was applied to examine the hypothesis. The data analysis through the path analysis approach using the PLS (partial least square) with the secondorder confirmatory factor analysis (Ghozali, 2012).

According to Latan and Ghozali (2012), the model evaluation in the PLS is conducted by assessing the result of model measurement, which is through the analysis of confirmatory factors by testing the validity and reliability of the latent constructs. Furthermore, it is continued by the structural model evaluation and significance test to examine the influence among constructs or variables.

3.3.6.1 Evaluation of measurement model (outer model). The evaluation of the measurement model or outer model was conducted to assess the model's validity and reliability. The outer model with a reflective indicator was evaluated through the convergent validity and discriminant validity of the latent constructs indicator and composite reliability, as well as Cronbach's alpha to block the indicator.

3.3.6.1.1 Convergent validity. Convergent validity is a correlation among score component items. According to Chin (1998), the adequate value is between 0.50 and 0.60 for development research and beyond 0.70 is considered high.

3.3.6.1.2 Discriminant validity. Discriminant validity is related to the principle that the different construct meters (manifest variable) should not correlate highly. The discriminant test can be conducted by examining the cross-loading with its latent variables or by comparing the square root of average extracted (AVE) value of each latent variable and the correlation among other latent variables within the model.

3.3.6.1.3 Composite reliability dan Cronbach's alpha. Testing construct reliability using the criteria of composite reliability. A group of indicators that measures a variable has good composite reliability if it has a value beyond 0.70 .

\subsection{Measurement model}

The measurement model test was related to the five variables in this research model. The following test results related to the measurement model. The validity of each item was shown in the correlatin value of $>0.30$ (Indarti et al., 2017). A mean between 3.5 and 4.49 indicated that this item was considered as high by the respondents, a mean between 4.50 and 5.00 indicated that this item was considered as very high by the respondents. The measurement model test is related to the five variables in this research model. The following test results relate to the measurement model. Validity of each itemize shown in value of correlatin $>0.30$ (Indarti et al., 2017). The mean between 3.5 and 4.49 indicate that this item 
JWL 32,1

is perceived high by the respondents, the mean between 4.50 and 5.00 indicate that this item is perceived very high by the respondents.

Based on Table I, it can be explained that all indicators and items significantly measured each variable. The result of analysis also showed that the strongest indicator as indicator of market orientation (X1) was CO1 indicator, with loading factor value equal to 0.817 , and the highest item was listening to customer opinion with loading factor value of 0.814 . In learning orientation variable $(X 2)$, it was known that the strongest indicator as the measure was CL, with loading factor value of 0.881 , and the highest item was establishing a relationship with the partner with the loading factor value of 0.873 . The analysis also shows that the strongest indicator as an indicator that proves entrepreneurship (X3) is the Innovative indicator, with a loading factor value of 0.835 , and the highest item finds a nonproduct way to create value for customers through distribution channels, salespeople and advertisements with value loading factor of 0.801 . In the knowledge competence variable (Y1), it was known that the strongest indicator (because of its size) was KC3 with item of having market knowledge with loading factor value of 0.811. In Innovation Variable (Y2), it was known that the strongest indicator as its measure was product innovation (IPd1) with loading factor value of 0.889 , and the highest item was the launching of new products considered by customers with the same loading factor value to 0.856 . In the business performance variable (Y3), it was known that the strongest indicator as the measure was BP3 (Y3) with the profit of the company's item increased during the last three years with the loading factor value of 0.891 .

\subsection{Test of linearity assumption}

In GSCA analysis, there is one assumption that must be fulfilled before the analysis, namely linearity assumption, which requires the relationship between variables that are linear (Fernandes and Solimun, 2017). The linearity assumption using the Curve Fit method is the relationship between the variables are linear if fulfill one of the following two possibilities: (1) significant linear model (linear model sig $<0.05$ ), (2) non-significant linear model and all possible non-significant models (linear model sig $>0.05$, and sig model other than linear $>$ 0.05). The test results show that the linear model value is $<0.05$ so that the model is said to be linear and meets the specified assumptions.

\subsection{Goodness of fit}

Based on the feasibility test result of model structurally measured by using FIT and AFIT, it is obtained FIT value of 0.875 and AFIT value of 0.730 . The FIT value explains that the total diversity that the model can explain is 87.5 per cent. It means that the model formed can explain all the existing variables by 87.5 per cent. The diversity of Market Orientation variables, learning orientation, competence of knowledge, innovation, and business performance can be explained by the model of 87.5 per cent, and the remaining 12.5 per cent can be explained by other variables outside the model. While the overall model feasibility test results measured using GFI and SRMR, it is obtained GFI value of 0.923 and SRMR value of 0.045 . GFI value greater than 0.900 and SRMS value less than 0.08 indicates that the model used is good fit.

\section{Result and discussion}

\subsection{Direct effect of structural model}

Direct effect showed the direct relationship between variables. The results of the model (as shown in Table II) showed that there was direct correlation. The results supported H1. The correlation value of market orientation with knowledge competence was $(\beta=0.453, p<$ 0.000). The value of regression coefficient was positive 0.453 , and $p$ value was $(0.000<0.05)$, 


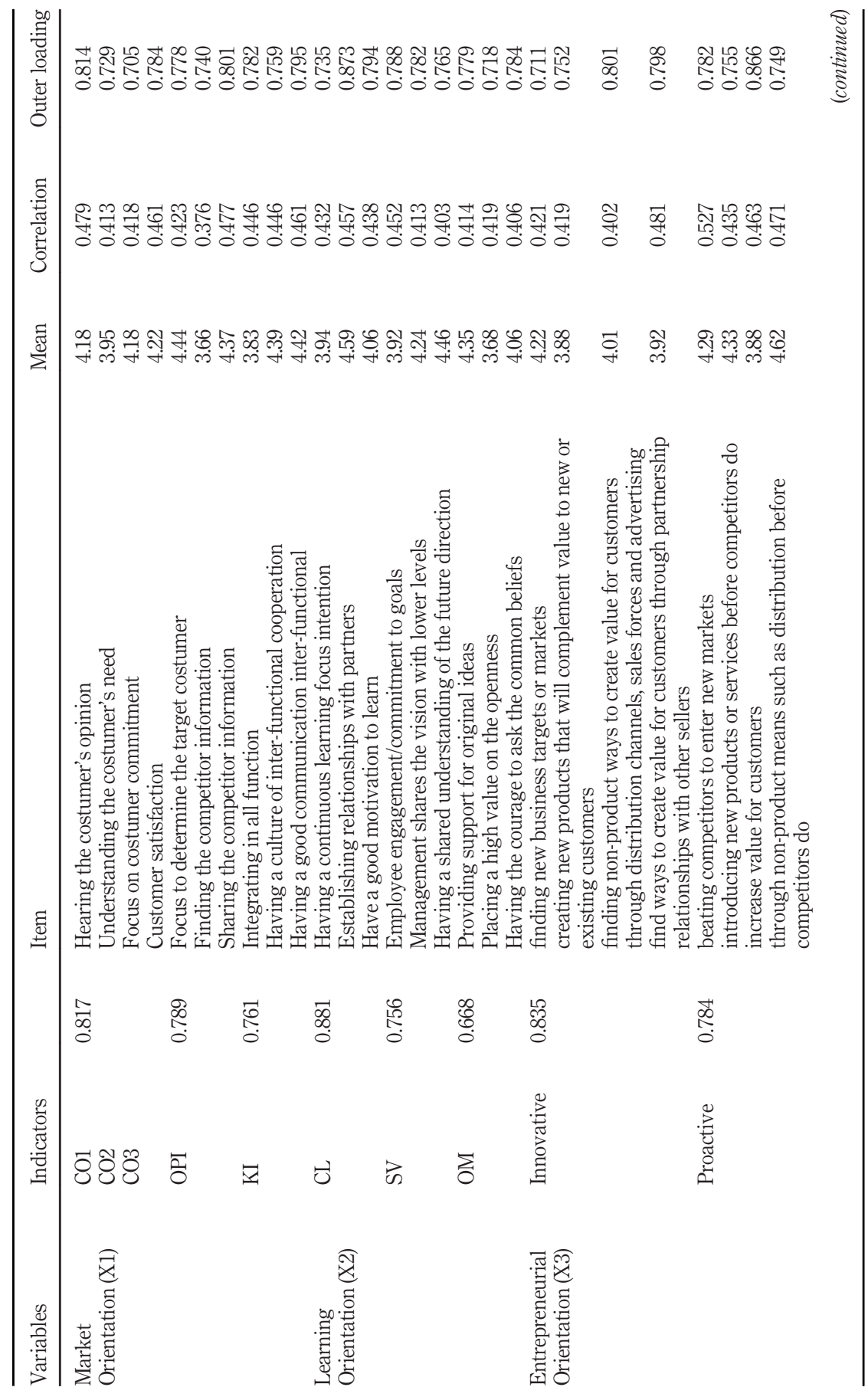

Orientation variables on business performance

Table I. Mean, correlation and outer loading 
JWL
32,1

50

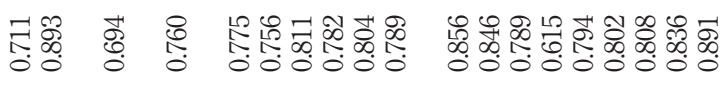

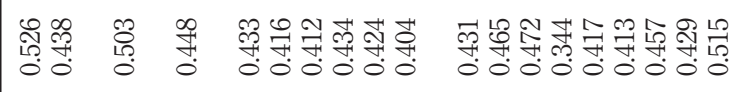

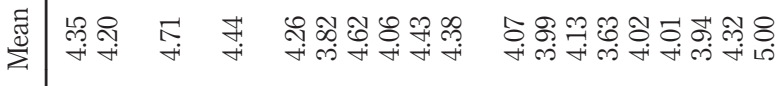

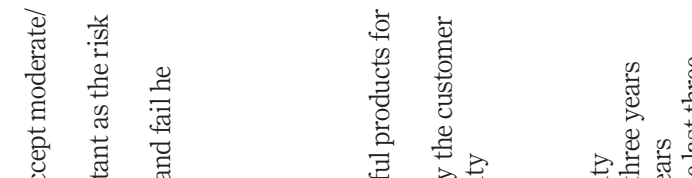

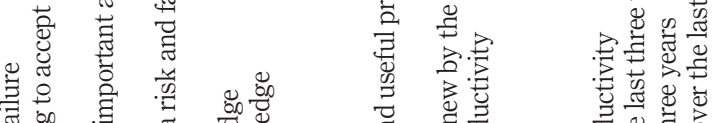

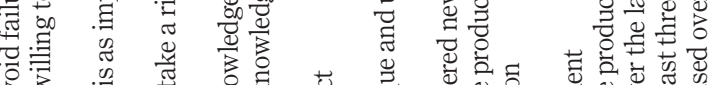
至

薄 劳

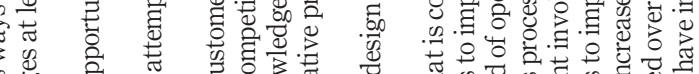

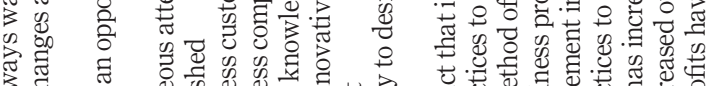

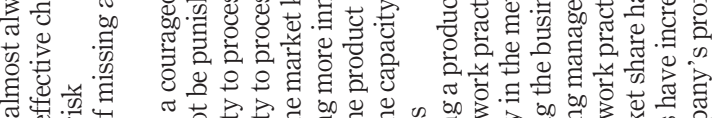

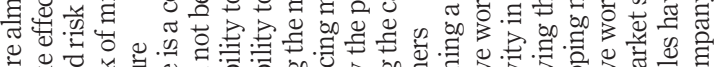

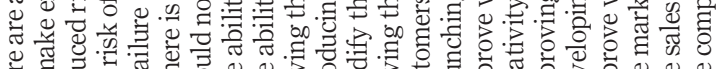

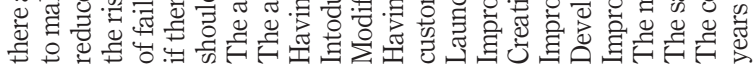
(1)

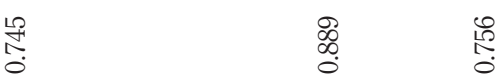

Table I.

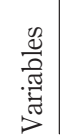
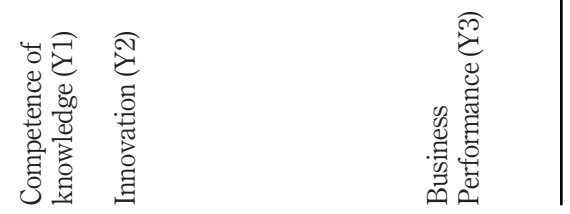
which was significant. Therefore, it can be concluded that market orientation had a significant positive effect on knowledge competence. It supported $H 2$. The correlation value of learning orientation with knowledge competence was $(\beta=0.449, p<0.000)$. The value of regression coefficient was positive 0.449 , and $p$ value was $(0.000<0.05)$, which was significant. Thus It supported $H 3$, The correlation value of entrepreneurial orientation with knowledge competence was $(\beta=0.392, p<0.000)$. The value of regression coefficient was positive 0.392 , and $p$ value was $(0.000<0.05)$, which was significant. The results supported $H 4$. The correlation value of entrepreneurial orientation with business performance was $(\beta=0.200, p<0.000)$. The value of regression coefficient was positive 0.200 , and $p$ value was $(0.001<0.05)$, which was significant. The results supported $H 5$. The correlation value of innovation with business performance was $(\beta=0.655, p<0.000)$. The value of regression coefficient was positive 0.655 , and $p$ value was significant $(0.000<0.05)$.

As a consequence, it can be concluded that innovation had a significant positive effect on business performance. The results supported $H 6$.

\subsection{Indirect effect}

Mediation criteria can be measured by multiplying the direct effect by using Sobel Test (Solimun and Fernandes, 2017). The test results of indirect effect can be presented as follows (Table III). Table III showed the test results of indirect effect of market orientation on innovation with knowledge competence mediation, where the value of indirect effect coefficient was positively significant ( $\beta=0.210, p<0.011$ ). It can be concluded that market orientation indirectly had a significant positive effect on innovation through knowledge competence. The results supported H7. The test results of indirect effect of learning orientation on innovation with knowledge competence mediation showed that the value of indirect effect coefficient was positively significant $(\beta=0.172, p<0.021)$. It can be concluded that learning orientation indirectly had a significant positive effect on innovation through knowledge competence. The results supported $H 8$.

The test results of indirect effect of entrepreneurial orientation on innovation with knowledge competence mediation showed that the value of indirect effect coefficient was

\begin{tabular}{lccc}
\hline Relationship between variable & Path coefficient & $p$-value & Explanation \\
\hline H1: Market Orientation $\rightarrow$ Competence of knowledge & 0.453 & 0.000 & significant \\
H2: Learning Orientation $\rightarrow$ Competence of knowledge & 0.449 & 0.000 & significant \\
H3: Entrepreneurial Orientation $\rightarrow$ Competence of knowledge & 0.392 & 0.000 & significant \\
H4: Entrepreneurial Orientation $\rightarrow$ Business Performance & 0.200 & 0.001 & Significant \\
H5: Competence of knowledge $\rightarrow$ Innovation & 0.625 & 0.000 & significant \\
H6: Innovation $\rightarrow$ Business Performance & 0.655 & 0.000 & Significant \\
\hline
\end{tabular}

Table II. Direct effect of structural model

\begin{tabular}{lcc}
\hline Indirect effect & Original Sample $(\mathrm{O})$ & $p$-values \\
\hline Market orientation $\rightarrow$ Innovation & 0,210 & 0,011 \\
Learning orientation $\rightarrow$ Innovation & 0,172 & 0,021 \\
Entrepreneurial Orientation & 0,199 & 0,031 \\
Market orientation $\rightarrow$ Business performance & 0,104 & 0,000 \\
Learning orientation $\rightarrow$ Business performance & 0,102 & 0,000 Table III. \\
Entrepreneurial Orientation $\rightarrow$ Business Performance & 0,193 & 0.000 \\
\end{tabular}


JWL 32,1

positively significant $(\beta=0.199, p<0.031$ ). It can be concluded that entrepreneurial orientation indirectly had a significant positive effect on innovation through knowledge competence. The results supported H9. The test results of indirect effect of market orientation on business performance which was mediated by knowledge competence and innovation showed that the value of indirect effect coefficient was positively significant $(\beta=0.104, p<0.000)$. So it can be concluded that knowledge competence and innovation mediated the effect of market orientation on business performance. The results supported H1O. The test results of indirect effect of learning orientation on business performance that was mediated by knowledge competence and innovation showed that the value of indirect effect coefficient was positively significant $(\beta=0.102, p<0.000)$. The results supported H11. The test results of indirect effect of entrepreneurial orientation on business performance that was mediated by knowledge competence and innovation showed that the value of indirect effect coefficient was positively significant $(\beta=0.193, p<0.000)$. Thus, it can be concluded that knowledge competence and innovation mediated the effect of entrepreneurial orientation on business performance. The results of the study supported H12.

Manufacturing SMEs surveyed by the researchers showed that the level of innovation and business performance were the main reasons for developing the concepts of market orientation, learning orientation, and knowledge competence. The current literature explored the concept of knowledge competence in the western context in large enterprises, how industrial SMEs understand the concept was still less understood by people (Ozkaya et al., 2015).

It can be concluded from the positive outcomes of the relationship between learning orientation and innovation that learning ability might support organizations in introducing new processes, ways and products. According to Chen et al. (2009), successful innovation occurs when companies commit to learning. More management organizations which encouraged learning orientation meant that there were more open-minded organizations which had information and knowledge about customers, then it meant that there were more companies that were able to offer more valuable products. Furthermore, the high level of learning orientation became an important predictor of innovation. This finding was in line with Calantone $e t$ al. (2002), who suggested learning orientation as an innovation antecedent. The results also supported the findings of Wolff et al. (2015), who argued that learning orientation created a set of knowledge values that facilitated the company to be creative in operating methods, trying out new ideas that contribute to innovation ability. The results provided further support to Calisir et al. (2013), which stated that learning orientation had a significant positive impact on innovation. A culture of open-mindedness allowed companies to gain new information, knowledge and insights so that new ideas that supported the innovation process emerged.

However, statistical test results indicated that market orientation had an insignificant influence on innovation. That was, market orientation in SMEs of the textile industry had little direct correlation with innovation, or innovation was less predictable by market orientation. The results of this study were inconsistent with Mahmoud's (2016) study that examined Gana's banking sector that the country's market orientation required companies to continuously observe rapidly changing customer needs and desires, and adapt to the impact of those changes by innovating. The results also did not support the study of Newman et al. (2016) and Zhang and Duan (2010) study, who found that market orientation allowed companies to seek, deploy and respond to market information. Information provided an opportunity for the organization to make decisions, including the decision to innovate. Market orientation that did not have a significant effect on innovation showed that 
market orientation will not result in product innovation development without the ability to properly implement new product development plans. Customer orientation can lead to limited ability to develop new ideas and to release new products. Customers often fail to understand their potential needs; there was a shift in industrial technology trends and in a stable customer population. A close relationship with customers limited the innovation of a product or an uncompetitive new product, creating a routine trap that jeopardized the creativity of a new product. Similarly, competitor orientation might hamper the company's products because of increased learning to imitate. As a result, companies get nothing but redoing a competitive advantage. Inter-functional coordination can hinder product innovation by encouraging group thinking, and internal orientation, thereby stopping companies from diverse market demands (Lin et al., 2012).

Furthermore, market orientation led to the positive effects of knowledge competence. If the market orientation was stronger, then the knowledge competence was better. The results supported previous research that found that market orientation had a positive and significant impact on knowledge competence (Li and Calantone, 1998). Based on RBV, customer and competitor orientations that showcased culture and market focus contributed significantly to market knowledge-related processes and capabilities. Ozkaya et al. (2015) found that market orientation as a culture and behavior, which understood the customers by finding market information, enhanced the mechanism of information transformation into new knowledge. Thus, a company that focused on market orientation was able to create knowledge competence.

The positive and significant effect of learning orientation on knowledge competence indicated if the learning orientation was stronger, then the knowledge competence was better. Knowledge competence can be improved by improving the learning orientation by having a learning commitment, being open minded to receive positive new things, and sharing the vision. The results of this study supported the results of research conducted by $\mathrm{Wu}$ and Lin (2013) which stated that learning orientation affected the effectiveness of knowledge competence. The effective knowledge competence depended on the sender's effort to share knowledge through the learning orientation. The process of learning orientation was not only done within the organization, but also by engaging in interactions outside the organization such as engaging in an early-stage interactive dialogue with customers, playing a mechanism that influenced a company's ability to ask questions and challenging old beliefs and sharpening cultures that can learn to improve the effectiveness of knowledge competence. This study supported previous research studies, such as Griese et al. (2012), Foong and Khoo (2015) which stated that learning orientation as the view and behavior of the importance of seeking and possessing knowledge, encouraged commitment to learning through relationships with customers and stakeholders, was capable of increasing the base of knowledge competence.

Related to the relationship of knowledge competence on innovation, the results of this study showed a significant positive effect. It meant that if the knowledge competence related to the market was higher, then the ability of innovation would be better. Organizations can improve their level of innovation by increasing the ability to translate customer information into knowledge to create innovative products, in comparison with the ability to translate competitor information into knowledge to create products and have market knowledge. The results supported previous research (De Luca and Atuahene-Gima, 2007; Hoe, 2015; Chang et al., 2015). The RBV theory provided an explanation that organizational capabilities were a source of competitive advantage. Knowledge competence as a series of information acquisition processed by regularly meeting customers, interpreting and integrating information into product and service designs enabled innovation as the company's ability to 
JWL

32,1

create and use knowledge resources, thus, increasing motivation to innovate, and ultimately competitive advantage (Janssen et al., 2014) .

The positive and significant effect of innovation on business performance meant that if the level of innovation increased, then business performance was higher. Profit growth as an indicator of business performance might increase if the dominant organization innovated the product as opposed to innovating the process. The results supported previous research (Rosenbusch et al., 2010; Roach et al., 2014), who suggested that innovation-oriented cultures that consisted of innovation orientation, innovation processes, and innovation inputs, created sales growth. Saunila and Ukko (2012) added innovation as the ability to transform, explore ideas and knowledge into new processes, systems, and products that drove financial and non-financial performance.

\subsection{Effects of knowledge competence mediation}

The results of the study found indirect effects through the role of knowledge competence in the relationship of market orientation and innovation. This means that knowledge competence acted as a full mediation between market orientation and innovation. These results were consistent with the research results of Ozkaya et al. (2015), who found that market orientation applied to companies in the west (USA) had a significant positive effect on innovation through knowledge competence mediation. It can be caused by a deep understanding of the needs and desires of customers; the desire to provide customer satisfaction; the habit of always listening to customers' opinions and desires; that had inadvertently shaped the knowledge of SME managers of the textile industry in creating innovation. Research on the role of knowledge competence in mediating the effect of market orientation on innovation supported previous researches (Li and Calantone, 1998; De Luca and Atuahene-Gima, 2007; Bhatnagar and Gopalaswamy, 2017).

Knowledge competence had a role as a mediator of the influence of learning orientation on innovation, meaning that knowledge competence had the capacity to increase innovation. A strong learning orientation supported knowledge competence to enhance innovation. Knowledge competence that was demonstrated by the ability to process customer knowledge, to process competitor knowledge, and have high market knowledge made SME innovations from the textile industry were increasing. The results supported the statement that learning orientation was able to explain the influence of knowledge competence on innovation, thus, learning orientation became an important predictor of knowledge competence and innovation. Supporting research in China (Wu and Lin, 2013), a strong learning orientation supported knowledge competence. The results also supported research conducted in Germany (Griese et al., 2012), which showed a focus on learning values: learning commitment, shared vision that guides and direct learning, and open-mindedness, supported by human resource practices in enhancing organizational skills to gain knowledge competence. As a result, applied knowledge will drive innovation.

\section{Conclusion and recomendation}

\subsection{Conclusion}

Based on the results of descriptive and inferential analysis that has been conducted, it can be concluded that the answer to the problems and objectives that have been determined is market orientation, learning orientation and entrepreneurial orientation affect business performance through knowledge competence and innovation directly and its influence is significantly positive. but market orientation, learning orientation and entrepreneurial orientation do not directly have a significant positive effect on innovation through knowledge competence. Market orientation, learning orientation and entrepreneurship 
orientation indirectly have a significant positive effect on business performance through knowledge and innovation competencies.

\subsection{Recommendation}

The suggestion that can be given to the next researcher is to continue the research about market orientation on business performance related to the ability of other companies, and can make a research on different area that is on different geographical, different kind of business, but still in industry SME sector. While the suggestion for SMEs and governments is aligning and integrating the pattern of company operations with the principles of marketoriented, learning orientation, competence of knowledge, and innovation, increasing the efforts to offer customer satisfaction, actively seek and share information related to competitors, strengthen the inter-functional coordination by increasing integration in all function, the Provincial Government of Bali can play a role in developing SMEs textile industry in Bali by providing training, especially managerial and utilization of information technology, and implement the ability of innovation.

\subsection{Implications}

The expectation of this research is the findings that can benefit businessmen in Bali in attempts to improve business innovation and performance. the market and learning orientation as the organizational culture that constitutes business behavior and knowledge competency as organizational resources can be used in the business or strategic practices to create innovation and achieve business performance.

5.3.1 Theoretical implication. This research contributes to the development of marketing management science, especially the marketing strategy by emphasizing the role of market orientation, learning orientation, and knowledge competency in improving business innovation and performance. the research findings empirically prove that business innovation and performance is constructed upon market orientation, learning orientation, and knowledge competency.

The RBV view provides a suitable theoretical framework to examine resources based on the market, which is the interaction of the components of organizational culture as a reflection of market-oriented values, norms, and faiths focused on the actual behavior to be proactive in collecting information of customers and competitors and monitoring the level of organizational commitment in providing the consumers' need to create business performance (Raju et al., 2011; Roach et al., 2014) through the concept of knowledge and innovation competency (Ozkaya et al., 2015; Hult et al., 2004). This research supports the RBV theory (Barney, 1991) which states that competency is a specific intangible resource that is influential to business competitiveness and performance.

The resource-based theory emphasizes the importance of effective resource distribution strategy to create value, maintain competitiveness, and create superior profitability. The $\mathrm{RBV}$ theory can explain the organization competency to be categorized as resources, such as market orientation and learning orientation which have effects on the innovation that will assist the organization in exploiting the capability to reach sustainable competitiveness (Lages et al., 2009; Raju et al., 2011; Srivastava et al., 2016).

The role of knowledge competency can be explained by the basic of the RBV theory. It is an ability to integrate information to the knowledge of product/service design, which is a reflection of knowledge competency resources in attempts to achieve better results. The findings of this research strengthen the concept of performance (Barney, 1991) which emphasizes the importance of resources in improving business performance. The
Orientation variables on business performance 
JWL 32,1

competency as specific intangible ability/resources is related to the managerial practices including determining the company strategy, which is innovation.

The findings support the resource dependence theory which can explain the relations of learning orientation and knowledge competency. The organization needs to establish learning orientation through a relationship with the external environmental factor and internal collaboration in coping with the environmental uncertainty to improve the knowledge competency.

These research findings support the theory of reasoned action which can explain the relationship between behavioral learning orientation creating knowledge competency (Ajzen, 1991). Behavior determines attitude. Attitude and perception of the importance of learning as a reaction to the business environment changes will create intention and behavior to improve knowledge competency as a foundation that encourages business innovation and performance.

5.3.2 Practical implications. This research proves that the synergized relationship of market orientation, learning orientation and knowledge competency are admitted as the primary variable which role is important in encouraging business innovation and performance. The research findings are also expected to contribute practically in relation to the understanding of how roles can actualize business innovation and performance. Based on the findings and discussion, the recommendations to improve the textile industry SMEs innovation and performance can be elaborated as follows:

Business innovation and performance can be improved by strengthening customer orientation by improving the activities of listening to customers' opinion (OPL1). The practices of listening to the customers' opinion, discussion, and exchanges of ideas with the customers or even with potential customers through activities in social media, such as Instagram, will give information, suggestion, feedback, and occurrence of new ideas to strengthen the strategic decision-making.

The orientation of competitors can be strengthened by improving the activities of competitors information exchange (OPE3). Managers, along with the employees, can share information acquired through organization activities by participating in industrial association meetings, discussing the strategy that is used by the competitors, including their achievements and weakness, will afford the company information regarding the competitors strengths and weaknesses, and furthermore, this information is shared to the entire departments in the organization to realize customer target.

The inter-functional coordination can be implemented by re-strengthening the cooperation culture between functions (KI2). The cooperation culture in the business process enables the information exchange, resources distribution and alignment of goals to achieve the common goals in attempts to provide superior customer values.

The learning orientation of textile industry SMEs managers can be improved if strengthening the learning commitment is by encouraging a stronger learning motivation and build a relationship with business partners. The learning culture to seek for understanding, information, and new knowledge in the environment can be conducted by strengthening the intensity of relationship with the customers, distributors, suppliers and partnership/relationship with the government through training and education program organized by the government.

Sharing vision can be improved by improving the management routine to share the vision with the lower levels (BV2). For examples, the manager routinely organizes a weekly meeting with the organization members to remind them of the organization's objectives and the strategic steps must be conducted to achieve the objective of the fulfillment of customers' needs, including the learning strategy. 
The open-mindedness can be implemented in textile industry SMEs by placing a high value to openness and cultivating the courage to question the pre-existing operational routines. The activities of questioning through traditional ways that have been implemented in perceiving the market information and evaluating the operational routines critically, improving the openness culture because the organization members typically are the source of new ideas, improving training, emphasizing the culture of correcting each other, and the tolerance of failure that will increase the open-mindedness as a process of learning to replace old knowledge and add the basis of pre-existing knowledge.

The textile industry SMEs' knowledge competency can be improved by improving the ownership of market knowledge. The implementation of market knowledge strengthening is implemented by textile industry SMEs by seeking the market information, interpreting, and transforming the information into knowledge, then the knowledge is used to make a strategic decision related to the innovation.

Innovation can be improved by strengthening product innovation by launching new products. Following the development of technology and market, which has grown faster and moved dynamically, forces the company to actively launch products considered new by the customers and in attempts to constantly observe the competitive environment, causing the company to continuously adapt to the changes of consumer preference through new products. The new products make regular customers stay amidst high business competition.

The innovation process of the textile industry SMEs can be improved if the SMEs heighten the work practices improvement to encourage productivity. It can be implemented by evaluating the pre-existing work practices and revising the practices or process steps that are not efficient in terms of cost and time.

\section{References}

Ajzen, I. (1991), "The theory of planned behavior", Organizational Behavior and Human Decision Processes, Vol. 50 No. 2, pp. 179-211.

Al-Ansari, Y., Pervan, S. and Xu, J. (2013), "Innovation and business performance of SMEs: the case of dubai”, Education, Business and Society: Contemporary Middle Eastern Issues, Vol. 6 Nos 3/4, pp. 162-180.

Atuahene-Gima, K. and Wei, Y. (2010), "The vital role of problem-solving competence in new product success", Journal of Product Innovation Management, Vol. 28 No. 1, pp. 81-98.

Baker, W.E. and Sinkula, J.M. (2005), "Market orientation and the new product paradox", Journal of Product Innovation Management, Vol. 22 No. 6, pp. 483-502.

Barney, J. (1991), "Firm resources and sustained competitive advantage", Journal of Management, Vol. 17 No. 1, pp. 99-120.

Batra, S., Sharma, S., Dixit, M.R., Vohra, N. and Gupta, V.K. (2015), "Performance implications of industry appropriability for manufacturing SMEs the role of technology orientation", Journal of Manufacturing Technology Management, Vol. 26 No. 5, pp. 660-677.

Beitler, M.A. and Mitlacher, L.W. (2007), "Information sharing, self-directed learning and its implications for workplace learning”, Journal of Workplace Learning, Vol. 19 No. 8, pp. 526-536.

Bhatnagar, N. and Gopalaswamy, A.K. (2017), "The role of a firm's innovation competence on customer adoption of service innovation”, Management Research Review, Vol. 40 No. 4, pp. 378-409.

Brem, A. and Voigt, K.I. (2009), "Integration of market pull and technology push in the corporate front end and innovation management - insights from the German software industry", Technovation, Vol. 29 No. 5, pp. 351-367.

Calantone, R.J., Cavusgil, S.T. and Zhao, Y. (2002), "Learning orientation, firm innovation capability and firm performance”, Industrial Marketing Management, Vol. 31 No. 6, pp. 515-524. 
JWL 32,1

Calisir, F., Gumussoy, C.A. and Guzelsoy, E. (2013), "Impacts of learning orientation on product innovation performance", The Learning Organization, Vol. 20 No. 3, pp. 176-194.

Carbonell, P. and Escudero, A.I.R. (2010), "The effect of market orientation on innovation speed and new product performance", Journal of Business and Industrial Marketing, Vol. 25 No. 7, pp. 501-513.

Chang, J., Bai, X. and Li, J.J. (2015), "The influence of leadership on product and process innovations in China: the contingent role of knowledge acquisition capability", Industrial Marketing Management, Vol. 50.

Chen, Y.S., Lin, M.J.J. and Chang, C.H. (2009), "The positive effects of relationship learning and absorptive capacity on innovation performance and competitive advantage in industrial markets", Industrial Marketing Management, Vol. 38 No. 2, pp. 152-158.

Chin, W.W. (1998), "The partial least squares approach for structural equation modeling", in Marcoulides, G.A. (Ed.), Modern Method for Business Research, Erlbaum, Mahwah, NJ.

Chung, H.F.L. (2012), "Export market orientation, managerial ties, and performance", International Marketing Review, Vol. 29 No. 4, pp. 403-423.

Clulow, V., Barry, C. and Gerstman, J. (2007), "The resource-based view and value: the customer-based view of the firm", Journal of European Industrial Training, Vol. 31 No. 1, pp. 19-35.

Coetzer, A. (2007), "Employee perceptions of their workplaces as learning environments", Journal of Workplace Learning, Vol. 19 No. 7, pp. 417-434.

Damanpour, F. (1991), "Organizational innovation: a meta-analysis of effects of determinants and moderators", Academy of Management Journal, Vol. 34 No. 3, pp. 555-590.

Darroch, J. (2005), "Developing a measure of knowledge management behavior and practices", Journal of Knowledge Management, Vol. 7 No. 5, pp. 41-54.

Day, G.S. (1994), “The capabilities of market-driven organizations”, Journal of Marketing, Vol. 58 No. 4, pp. 37-52.

De Luca, L.M. and Atuahene-Gima, K. (2007), "Market knowledge dimensions and cross-functional collaboration: examining the different routes to product innovation performance", Journal of Marketing, Vol. 71 No. 1, pp. 95-112.

Fang, R., Landis, B., Zhang, Z., Anderson, M.H., Shaw, J.D. and Kilduff, M. (2015), "Integrating personality and social networks: a Meta-analysis of personality, network position, and work outcomes in organizations", Organization Science, Vol. 26 No. 4, pp. 1243-1260.

Fernandes, A.A.R. and Solimun, F. (2017), "The mediation effect of strategic orientation and innovations on the effect of environmental uncertainties on performance of business in the indonesian aviation industri”, International Journal of Law and Management, Vol. 59 No. 6, pp. 11-20.

Foong, S.Y. and Khoo, C.H. (2015), "Attitude, learning environment and current knowledge enhancement of accounting students in Malaysia", Journal of Accounting in Emerging Economies, Vol. 5 No. 2, pp. 202-221.

Frank, H., Kessler, A., Mitterer, G. and Weismeier-Sammer, D. (2012), "Learning orientation of SMEs and its impact on firm performance", Journal of Marketing Development and Competitiveness, Vol. 6 No. 3, pp. 29-41.

Fuller, A. and Unwin, L. (2005), "Older and wiser? Workplace learning from the perspective of experienced employees”, International Journal of Lifelong Education, Vol. 24 No. 1, pp. 21-39.

Ghozali, I. (2012), Structural Equation Modeling. Alternative Methods with Partial Least Square, Vol. 2, Diponegoro University Publisher Agency, Semarang.

Gotteland, D. and Boulé, J.M. (2006), "The market orientation-new product performance relationship: redefining the moderating role of environmental conditions", International Journal of Research in Marketing, Vol. 23 No. 2, pp. 171-185. 
Griese, I., Pick, D. and Kleinaltenkamp, M. (2012), “Antecedents of knowledge generation competence and its impact on innovativeness", Journal of Business and Industrial Marketing, Vol. 27 No. 6, pp. 468-485.

Harmancigolu, N., Grinstein, A. and Goldman, A. (2010), "Innovation and performance outcomes of market information collection efforts: the role of top management tea involvement", International Journal of Research in Marketing, Vol. 27 No. 1, pp. 33-43.

Haryanto, A.T., Haryono, T. and Sawitri, H.S.R. (2017), "Market orientation, learning orientation and small medium enterprises performance: the mediating role of innovation", International Review of Management and Marketing, Vol. 7 No. 1, pp. 484-491.

Hilman, H. and Kaliappen, N. (2015), "Innovation strategies and performance: are they truly linked?”, World Journal of Entrepreneurship, Management and Sustainable Development, Vol. 11 No. 1, pp. 48-63.

Hilmi, M.F., Ramayah, T., Mustapha, Y. and Pawanchik, S. (2010), "Product and process innovativeness: evidence from Malaysian SMEs", The International Journal of Interdisciplinary Social Sciences: Annual Review, Vol. 16 No. 4, pp. 547-555.

Hoe, S.L. (2008), "Issues and procedures in adopting structural equation modeling technique", Journal of Applied Quantitative Method, Vol. 3 No. 1.

Huber, G.P. (1991), "Organizational learning: the contribution process and the literatures", Organization Science, Vol. 2 No. 1, pp. 88-115.

Huhtala, J.-P., Sihvonen, A., Frosen, J., Jaakkola, M. and Tikkanen, H. (2014), "Market orientation, innovation capability and business performance. Insights from the global financial crisis", Baltic Journal of Management, Vol. 9 No. 2, pp. 134-152.

Hult, G.T.M., Hurley, R.F. and Knight, G.A. (2004), "Innovativeness: its antecedents and impact on business performance", Industrial Marketing Management, Vol. 33 No. 5, pp. 429-438.

Illeris, K. (2004), “A model for learning in working life”, Journal of Workplace Learning, Vol. 16 No. 8, pp. 431-441.

Indarti, S., Solimun, F.A.A.R. and Hakim, W. (2017), "The effect of OCB in relationship between personality, organizational commitment and job satisfaction on performance", Journal of Management Development, Vol. 36 No. 10, pp. 1283-1293.

Janssen, W., Bouwman, H., van Buuren, R. and Haaker, T. (2014), "An organizational competence model for innovation intermediaries", European Journal of Innovation Management, Vol. 17 No. 1, pp. 2-24.

Jimenez, D.J. and Valle, R.S. (2011), "Innovation, organizational learning and performance", Journal of Business Research, Vol. 64 No. 4, pp. 408-417.

Johnson, F.O. and Atchison, W.D. (2009), "The role of environmental mercury, lead and pesticide exposure in development of amyotrophic lateral sclerosis", Neurotoxicology, Vol. 30 No. 5, pp. $761-765$.

Kandemir, D. (2005), "A studi of market competence of knowledge as a source of SBU performance", a dissertation.

Kaya, A.Z., Turani, N. and Akyüz, A. (2005), "The effectiveness of a hydrogel dressing compared with standard management of pressure ulcers", Journal of Wound Care, Vol. 14 No. 1, pp. $42-44$.

Keh, H.T., Nguyen, T.T.M. and dan Ng, H.P. (2007), "The effects of entrepreneurial orientation and marketing information on the performance of SMEs", Journal of Business Venturing, Vol. 22 No. 4, pp. 592-611.

Keskin, H. (2006), "Market orientation, learning orientation, and innovation capabilities in SMEs. An extended model”, European Journal of Innovation Management, Vol. 9 No. 4, pp. 396-417.

Kompas (2014), "Potential targets for Indonesian textile exports".

Latan, H. and Ghozali, I. (2012), Partial Least Squares. Concepts, Techniques and Applications. SmartPLS 2.0 M3. For Empirical Research, Diponegoro University Publisher Agency, Semarang. 
JWL 32,1

Li, T. and Calantone, R.J. (1998), “The impact of market competence of knowledge onnew product advantage: conceptualization and empirical examination", Journal of Marketing, Vol. 62 No. 4, pp. 13-29.

Lin, R.J., Che, R.H. and Ting, C.Y. (2012), “Turning knowledge management into innovation in the hightech industry", Industrial Management and Data Systems, Vol. 112 No. 1, pp. 42-63.

Lin, C.-H., Peng, C.-H. and Kao, D.T. (2008), "The innovativeness effect of market orientation and learning orientation on business performance", International Journal of Manpower, Vol. 29 No. 8 , pp. $752-772$.

Li, T. and Tamer Cavusgil, S. (1999), "Measuring the dimensions of market knowledge competence in new product development", European Journal of Innovation Management, Vol. 2 No. 3, pp. 129-146.

Lumpkin, G.T. and Dess, G.G. (1996), "Clarifying the entrepreneurial orientation construct and linking it to performance", Academy of Management Review, Vol. 21 No. 1, pp. 135-172.

McDermott, C.M. and Prajogo, D.I. (2012), "Service innovation and performance in SMEs", International Journal of Operations and Production Management, Vol. 32 No. 2, pp. 216-237.

Maheswari, H., Yudoko, G. and Adhiutama, A. (2017), "Stakeholder engagement in quattro helix model for mobile phone reverse logistics in Indonesia: a conceptual framework", In IOP Conference Series: Materials Science and Engineering, IOP Publishing, Vol. 277 No. 1, p. 012062.

Mahmoud, M.A., Blankson, C., Frimpong, O.N., Nwankwo, S. and Trang, T.P. (2016), "Market orientation, learning orientation and business performance: the mediating role of innovation", International Journal of Bank Marketing, Vol. 34 No. 5, pp. 623-648.

Mauludin, H., Alhabsji, T., Idrus, S. and Arifin, Z. (2013), "Market orientation, learning organization and dynamic capability as antecedents of value creation", Journal of Business and Management, Vol. 10 No. 2, pp. 38-48.

Najafi-Tavani, S., Sharifi, H. and Najafi-Tavani, Z. (2016), "Market orientation, marketing capability, and new product performance: the moderating role of absorptive capacity", Journal of Business Research, Vol. 69 No. 11, pp. 5059-5064.

Najib, M. and Kiminami, A. (2011), "Innovation, cooperation and business performance some evidence from Indonesian small food processing cluster", Journal of Agribusiness in Developing and Emerging Economies, Vol. 1 No. 1, pp. 75-96.

Narver, J.C. and Slater, S.F. (1990), "The effect of a market orientation on business profitability”, Journal of Marketing, Vol. 54 No. 4, pp. 20-35.

Nasution, H.N., Mavondo, F.T., Matanda, M.J. and Ndubisi, N.O. (2011), "Entrepreneurship: Its relationship with market orientation and learning orientation and as antecedents to innovation and customer value", Industrial Marketing Management, Vol. 40 No. 3, pp. 336-345.

Ndubisi, N.O. and Iftihkar, K. (2012), "Relationship between entrepreneurship, innovation and performance", Journal of Research in Marketing and Entrepreneurship, Vol. 14 No. 2, pp. 214-236.

Newman, A., Prajogo, D. and Atherton, A. (2016), "The influence of market orientation on innovation strategies", Journal of Service Theory and Practice, Vol. 26 No. 1, pp. 72-90.

Otero-Neira, C., Lindman, M.T. and FernáNdez, M.J. (2009), "Innovation and performance in SME furniture industries. An international comparative case study", Marketing Intelligence and Planning, Vol. 27 No. 2, pp. 216-232.

Ozkaya, H.E., Droge, C., Hult, G.T.M., Calantone, R. and Ozkaya, E. (2015), "Market orientation, knowledge competence, and innovation", International Journal of Research in Marketing, Vol. 32 No. 3, pp. 1-10.

Paloniemi, S. (2006), "Experience, competence and workplace learning", Journal of Workplace Learning, Vol. 18 Nos 7/8, pp. 439-450.

Raju, P.S., Lonial, S.C. and Crum, M.D. (2011), "Market orientation in the context of SMEs: a conceptual framework", Journal of Business Research, Vol. 64 No. 12, pp. 1320-1326. 
Rhee, J.P.T. and Lee, D.H. (2010), "Drivers of innovativeness and performance for innovative SMEs in South Korea: mediation of learning orientation", Technovation, Vol. 30 No. 1, pp. 65-75.

Roach, D.C., Ryman, J. and White, J. (2014), "Culture, conduct and innovation: a deconstruction of market orientation", Journal of Research in Marketing and Entrepreneurship, Vol. 16 No. 2, pp. 128-145.

Rosenbusch, N., Brinckmann, J. and Bausch, A. (2010), "Is innovation always beneficial? A metaanalysis of the relationship between innovation and performance in SMEs", Journal of Business Venturing, Vol. 26 No. 4, pp. 441-457.

Salleh, K.M., Sulaiman, N.L. and Talib, K.N. (2010), "Globalization's impact on soft skills demand in the Malaysian workforce and organizations: what makes graduates employable?", Proceedings of the UPI International Conference on Technical and Vocational Education and Training Bandung, Indonesia.

Saunila, M. (2014), "Innovation capability for SME success: perspectives of financial and operational performance", Journal of Advances in Management Research, Vol. 11 No. 2, pp. 163-175.

Saunila, M. and Ukko, J. (2012), "A conceptual framework for the measurement of innovation capability and its effect”, Baltic Journal of Management, Vol. 7 No. 4, pp. 355-375.

Saunila, M., Pekkola, S. and Ukko, J. (2014), "The relationship between innovation capability and performance: the moderating effect of measurement", International Journal of Productivity and Performance Management, Vol. 63 No. 2, pp. 234-249.

Selznick, P. (1957), Leadership in Administration: A Sociological Interpretation, Harper and Row.

Sheng, M.L. and Chien, I. (2015), "Rethinking organizational learning orientation on radical and incremental innovation in high-tech firms", Journal of Business Research, Vol. 69 No. 6, 2302-2308.

Sinkula, J.M., Baker, W.E. and Noordewier, T. (1997), “A framework for market-based organizational learning: linking values, knowledge, and behavior", Journal of the Academy of Marketing Science, Vol. 25 No. 4, pp. 305-318.

Skrinjar, R., Vuksic, V.B. and Indihar-Stemberger, M. (2008), "The impact of business process orientation on financial and non-financial performance", Business Process Management Journal, Vol. 14 No. 5, pp. 738-754.

Soimun, F. and Fernandes, A.A.R. (2017), "Investigation the mediating variable: what necessary? (Case study in management research)", International Journal of Law and Management, Vol. 59 No. 6, pp. 101-110.

Srivastava, S., Somasagara, R.R., Hegde, M., Nishana, M., Tadi, S.K., Srivastava, M. and Raghavan, S.C. (2016), "Quercetin, a natural flavonoid interacts with DNA, arrests cell cycle and causes tumor regression by activating mitochondrial pathway of apoptosis", Scientific Reports, Vol. 6, p. 24049 .

Suliyanto, S. and Rahab, R. (2012), "The role of market orientation and learning orientation in improving innovativeness and performance of small and medium enterprises", Asian Social Science, Vol. 8 No. 1.

Vicence, M., Abrantes, J.L. and Teixeira, M.S. (2015), "Measuring innovation capability in exporting firms: the INNOVSCALE", International Marketing Review, Vol. 32 No. 1, pp. 29-51.

Vitale, J.E., Smith, S.S., Brinkley, C.A. and Newman, J.P. (2002), "The reliability and validity of the psychopathy checklist - revised in a sample of female offenders", Criminal Justice and Behavior, Vol. 29 No. 2, pp. 202-231.

Wang, C.L. and Chung, H.F.L. (2013), "The moderating role of managerial ties in market orientation and innovation: an Asian perspective", Journal of Business Research, Vol. 66 No. 12, 2431-2437.

Wei, Y., Frankwick, G.L. and Nguyen, B.H. (2012), "Should firms consider employee input in reward system design? the effect of participation on market orientation and newproduct performance", Journal of Product Innovation Management, Vol. 29 No. 4, pp. 546-558.

Wernerfelt, B. (1984), "A resource-based view of the firm”, Strategic Management Journal, Vol. 5 No. 2 , pp. 171-180. 
JWL

32,1

62

Westerlund, M. and Rajala, R. (2010), "Learning and innovation in inter-organizational network collaboration”, Journal of Business \& Industrial Marketing, Vol. 25 No. 6, pp. 435-442, available at: https://doi.org/10.1108/08858621011066026

Wolff, J.A., Pett, T.L. and Ring, J.K. (2015), "Small firm growth as a function of both learning orientation and entrepreneurial orientation. An empirical analysis", International Journal of Entrepreneurial Behavior and Research, Vol. 21 No. 5, pp. 709-730.

Wong, S.K.S. (2013), "The role of management involvement in innovation", Management Decision, Vol. 51 No. 4, pp. 709-729.

Wu, L.-W. and Lin, J.-R. (2013), "Knowledge sharing and knowledge effectiveness: learning orientation and co-production in the contingency model of tacit knowledge", Journal of Business and Industrial Marketing, Vol. 28 No. 8, pp. 672-686.

Zhang, J. and Duan, Y. (2010), "Empirical study on the impact of market orientation and innovation orientation on new product performance of Chinese manufacturers", Nankai Business Review International, Vol. 1 No. 2, pp. 214-231.

\section{Further reading}

Bali Province Industry and Trade Office (2017), "Bali province industry and trade office".

Levinthal, D.A. (1991), "Organizational adaptation and environmental selection”, Organization Science, Vol. 2 No. 1, pp. 140-145.

\section{Corresponding author}

Ni Made Wahyunican is the corresponding author for this article.

For instructions on how to order reprints of this article, please visit our website: 